\title{
Prevalence and Risk Factors of Asymptomatic
} Plasmodium Infection in Gondar Zuria District, Northwest Ethiopia

\author{
Awoke Minwuyelet' \\ Tegegne Eshetu' \\ Dagnaneh Milikit ${ }^{\prime}$ \\ Yibeltal Aschale (D) ${ }^{2}$ \\ 'Department of Medical Parasitology, \\ School of Biomedical and Laboratory \\ Sciences, College of Medicine and Health \\ Sciences, University of Gondar, Gondar, \\ Ethiopia; ${ }^{2}$ Department of Medical \\ Laboratory Sciences, College of Health \\ Sciences, Debre Markos University, \\ Debre Markos, Ethiopia
}

This article was published in the following Dove Press journal: Infection and Drug Resistance

Background: Malaria is one of the major public health problems worldwide. In Ethiopia, an increase in malaria incidence may be attributed to the presence of community-wide asymptomatic Plasmodium infection. This study aims to assess asymptomatic Plasmodium infection and associated factors in Gondar Zuria district, Northwest Ethiopia.

Methods: A community-based cross-sectional study was conducted in Gondar Zuria district from May to June 2019. Angacha and Hamsafeg villages were randomly selected from Tachtseda and Hamsafeg kebeles, respectively. Fifty-three (53) households were selected using systematic random sampling to recruit a total of 251 study participants. Sociodemographic data were collected using structured questionnaires. Thin and thick blood films were prepared and examined for evidence of parasites. Data were entered and analyzed using SPSS version 23. The association between dependent (asymptomatic Plasmodium infection) and independent (sex, age group, family size and previous history of malaria) variables was explored using bivariate and multivariate logistic regression. Statistically significant association was declared at a $P$-value of $<0.05$.

Results: A total of 251 individuals were tested, of whom $53.4 \%$ were females and $33.5 \%$ were above the age of 30 years. The prevalence of asymptomatic Plasmodium infection was $12 \%$. The highest prevalence of malaria was observed in females $(6.4 \%)$ and among the age group $15-29$ years $(4.4 \%)$. The majority $(70 \%)$ of study participants had $<500$ parasites $/ \mu \mathrm{L}$ of blood. A high parasitemia level (ie $\geq 1000$ parasites/ $\mu \mathrm{L}$ of blood) was observed in the age group 15-29 years. Age group, bed net usage and previous history of malaria were significantly associated with asymptomatic Plasmodium infection $(P<0.05)$.

Conclusion: Asymptomatic Plasmodium infection remains an important public health problem in the study area. Further studies using more sensitive diagnostic methods are required to scale up the eradication and control program of malaria.

Keywords: asymptomatic malaria, Plasmodium infection, Gondar Zuria, Ethiopia

\section{Background}

Malaria remains a serious global health problem in terms of both morbidity and mortality, resulting in enormous medical, economic and social impacts. ${ }^{1-3}$ It is caused by the genus Plasmodium and transmitted by female anopheline mosquitoes. Plasmodium falciparum, Plasmodium vivax, Plasmodium malariae, Plasmodium ovale and Plasmodium knowlesi are Plasmodium species that infect humans, of which $P$. falciparum and $P$. vivax pose the greatest threat in humans. ${ }^{1,4}$ Although malaria mortality rates declined from 2015 to 2017 by $7.2 \%$ (from 469,000 in 2015
Correspondence: Yibeltal Aschale College of Health Sciences, Debre Markos University, P.O. Box 269, Debre Markos, Ethiopia

Tel +251922444340

Email yibeltal.aschale@yahoo.com
Infection and Drug Resistance 2020:13 3969-3975 
to 435,000 in 2017), malaria incidence has increased by $2.2 \%$ (from 214.2 million in 2015 to 219 million in 2017). This may imply the presence of some bottlenecks such as undetectable levels of parasitemia and the absence of sensitive diagnostic tools in the global effort of malaria elimination. ${ }^{5}$ At present, malaria transmission is sustained within populations regardless of effective treatment of active cases, as misdiagnosed asymptomatic individuals serve as potential gametocyte carriers and transmitters. ${ }^{6}$

Malaria is distributed mainly in three WHO regions, namely, the African region, Southeast Asian region and Eastern Mediterranean region. The African region is home to the highest number of malaria cases and deaths. ${ }^{7}$ In 2017, an estimated 200 million malaria cases and 404,550 million deaths were recorded in the African region. Plasmodium falciparum is the most prevalent species, accounting for $99.7 \%$ of estimated malaria cases. ${ }^{5}$

In Ethiopia, three-fourths of the land mass is malarious and $60 \%$ of the population is at risk. ${ }^{8}$ Transmission is intense in places where the longevity of the mosquito is higher because the parasite has enough time to complete its maturation within the mosquito. The transmission pattern is seasonal and unstable, consisting of two transmission seasons: major (September-December) and minor (April-June). The other months (January-March) and (July-August) typically represent low malaria transmission seasons in most communities. ${ }^{8-10}$

According to the Ethiopian Federal Ministry of Health report, there were about 2.2 million malaria cases (confirmed by either blood film examination or rapid diagnostic tests) and 662 deaths in all age groups, of which $64 \%$ was due to $P$. falciparum and $36 \%$ was due to $P$. vivax. ${ }^{8}$ Children with severe malaria frequently develop severe anemia, respiratory distress and cerebral malaria. Multiorgan failure is also common in adults. ${ }^{11}$ Malaria deaths have reduced by $98 \%$ from 2006 to 2017 (from 41,000 estimated deaths to 662). ${ }^{8}$ However, it is unclear whether this reversal and stagnation of malaria prevalence are associated with submicroscopic infections and sexual stage gametocytes.

The current Ethiopian malaria elimination strategy incorporates the use of artemisinin combination therapy (ACT) as the first-line drug for the treatment of uncomplicated $P$. falciparum and chloroquine (CQ) against $P$. vivax, and the use of indoor residual spraying (IRS) and longlasting insecticide-treated nets (LLITNs). ${ }^{3,12}$ The nationwide distribution of rapid diagnostic test (RDTs), ACTs, LLITNs and IRS in Ethiopia since 2005 has resulted in significant reductions in morbidity and mortality. ${ }^{12}$ However, a report published in 2018 showed that the incidence of malaria has been increasing, implying the presence of challenges ahead of the national malaria elimination strategic plan. ${ }^{8}$

Therefore, this study aims to assess the prevalence, parasitemia level and associated factors of asymptomatic Plasmodium infection with respect to population demography in Gondar Zuria district, Northwest Ethiopia. As a result, policymakers should pay attention to the basic guidelines on the prevention and control of asymptomatic Plasmodium infection to scale up malaria elimination efforts in Ethiopia and across malaria-endemic countries. In addition, this study could provide information to institutions in the country working on designing effective prevention and control strategies against malaria.

\section{Methods}

\section{Study Area and Period}

The study was conducted in Gondar Zuria district, Northwest Ethiopia, from May to June 2019. This district is located $45 \mathrm{~km}$ from Gondar town and $729 \mathrm{~km}$ from Addis Ababa, the capital of Ethiopia. The area of Gondar Zuria district is $1108.53 \mathrm{~km}^{2}$, with a population density of 188.4 people $/ \mathrm{km}^{13}$ According to the 2007 Ethiopian statistics agency, an average of five people were counted per household. It has a total annual rainfall of $1047.6 \mathrm{~mm}$, mean maximum temperature of $27.4^{\circ} \mathrm{C}$, mean minimum temperature of $14.7^{\circ} \mathrm{C}$ and relative humidity of $45 \%$. It is estimated that the district has an altitude ranging between 1750 and $2600 \mathrm{~m}$ above sea level, and it is found just to the north of Lake Tana. According to the zonal health department report, the district is malarious; the streams and irrigation water serve as permanent anopheline breeding sites during dry seasons. Gondar Zuria district has seven health centers and 44 health posts providing services for people in and around the district.

\section{Study Design}

A community-based cross-sectional study was conducted to determine the prevalence and associated factors of asymptomatic Plasmodium infections.

\section{Inclusion and Exclusion Criteria}

Individuals who are permanent residents of the district and aged 6 months or older were included. Individuals with clinical symptom of malaria and those taking antimalarial 
drugs 1 month prior to and during data collection were excluded.

\section{Sample Size Determination}

The required sample size was calculated using the singlepopulation proportion formula $\left(N=(Z \alpha / 2)^{2} P(1-P)^{*} D e E f /\right.$ $d^{2}$ ) considering a $95 \%$ confidence level, a design effect of 2, a margin of error of $4 \%$ and an asymptomatic Plasmodium prevalence of 5\%, from a previous study. ${ }^{14}$ By considering a $10 \%$ non-response rate, the final sample size became 251 .

\section{Sampling Technique}

A multi-stage sampling technique was used to select the representative sample size. Among the kebeles in Gondar Zuria district, two kebeles were selected randomly by a lottery method. The estimated numbers of households recruited for the study were proportionally allocated to the selected kebeles based on the existing household number using recent registration lists of households found at Health Post. To recruit study subjects, 53 households were selected from the two kebeles using a systematic random sampling technique. Finally, 251 individuals were selected from 53 households using a lottery method considering approximate family size per household.

\section{Operational Definition}

Asymptomatic Plasmodium Infection

A person with no recent history of symptoms and/or signs of malaria who shows laboratory confirmation of parasitemia was defined as having asymptomatic Plasmodium infection. ${ }^{15}$ An infection was considered asymptomatic when the individual's body temperature was $<37.5^{\circ} \mathrm{C}$ at presentation and there was no history of fever within the last 72 hours.

\section{Data Collection and Laboratory Methods}

A semi-structured questionnaire, which was prepared in English and the local vernacular language, was used to collect sociodemographic variables and relevant associated factors. Every household head (either father or mother) was interviewed during a house-to-house visit for data collection.

\section{Blood Film Examination and Determination of Parasitemia}

A capillary blood sample was collected aseptically from each study participant to prepare both thick and thin blood films using pre-labeled microscopic slides for the detection, identification and quantification of the Plasmodium parasite. The blood films were stained with $10 \%$ fresh Giemsa stain for 10 minutes. After the stained slides were air-dried, both thick and thin blood films were examined at a magnification power of $100 \times$ to detect and identify Plasmodium parasites (both asexual and gametocyte stages). A slide was considered as negative if no Plasmodium parasite was detected after examination of 200 fields. Parasite densities were determined against 200 leukocytes assuming a standard mean white blood cell count of 8000 leukocytes $/ \mu \mathrm{L}$ of blood. ${ }^{16}$

\section{Data Management and Analysis}

The data were appropriately coded and entered into SPSS version 23 software, then checked for completeness and cleanness before analysis. Homogeneity and normality of continuous variables were checked by Levene's test and the Kolmogorov-Simonov test, respectively. Then, the study findings were explained in tables and graphs. The chi-squared test, bivariate and multivariate analysis were used to assess significant associations among variables. Potential malaria-associated factors that showed $P$-values $<0.25$ in the bivariate analysis were selected and entered for multivariate logistic regression to control confounding factors. A $P$-value $<0.05$ was taken as statistically significant.

\section{Results}

\section{Sociodemographic and Clinical Characteristics}

A total of 251 individuals were included in this study, of whom $53.4 \%(\mathrm{n}=134)$ were females. Their mean age was 24.6 years (range $1-82$ years) with a standard deviation of 20.9. One-third (33.5\%) of the participants were above 30 years old. The majority (67.7\%) of participants had a family size of more than five and $62.5 \%$ of participants had a previous history of malaria (Table 1).

\section{Prevalence of Asymptomatic Plasmodium Infection}

The overall prevalence of asymptomatic Plasmodium infection was $12 \%(30 / 251)$, of which males and females accounted for $5.6 \%$ and $6.4 \%$, respectively. Plasmodium falciparum and $P$. vivax were identified, with infection prevalences of $2 \%(5 / 251)$ and $10 \%(25 / 251)$, respectively. The relative proportions of Plasmodium species in positive 
Table I Sociodemographic Characteristics of Study Participants in Gondar Zuria District, Northwest Ethiopia, 2019

\begin{tabular}{|c|c|c|c|}
\hline $\begin{array}{l}\text { Sociodemographic } \\
\text { Variables }\end{array}$ & Category & Frequency & Percentage \\
\hline Sex & $\begin{array}{l}\text { Male } \\
\text { Female }\end{array}$ & $\begin{array}{l}117 \\
134\end{array}$ & $\begin{array}{l}46.6 \\
53.4\end{array}$ \\
\hline Age group (years) & $\begin{array}{l}<5 \\
5-14 \\
15-29 \\
30 \text { and } \\
\text { above }\end{array}$ & $\begin{array}{l}33 \\
81 \\
53 \\
84\end{array}$ & $\begin{array}{l}13.1 \\
32.3 \\
21.1 \\
33.5\end{array}$ \\
\hline Marital status & $\begin{array}{l}\text { Married } \\
\text { Single } \\
\text { Widowed/ } \\
\text { divorced }\end{array}$ & $\begin{array}{l}96 \\
142 \\
13\end{array}$ & $\begin{array}{l}38.2 \\
56.6 \\
5.2\end{array}$ \\
\hline Educational status & $\begin{array}{l}\text { Unable to } \\
\text { read and } \\
\text { write } \\
\text { Read and } \\
\text { write } \\
\text { Primary } \\
\text { school and } \\
\text { above }\end{array}$ & $\begin{array}{l}150 \\
86 \\
15\end{array}$ & $\begin{array}{l}59.7 \\
34.3 \\
6.0\end{array}$ \\
\hline Kebele & $\begin{array}{l}\text { Tachtseda } \\
\text { Hamsafeg }\end{array}$ & $\begin{array}{l}131 \\
120\end{array}$ & $\begin{array}{l}52.2 \\
47.8\end{array}$ \\
\hline Household size & $\begin{array}{l}\mathrm{I}-5 \\
>5\end{array}$ & $\begin{array}{l}81 \\
170\end{array}$ & $\begin{array}{l}32.3 \\
67.7\end{array}$ \\
\hline $\begin{array}{l}\text { Previous history of } \\
\text { malaria }\end{array}$ & $\begin{array}{l}\text { Yes } \\
\text { No }\end{array}$ & $\begin{array}{l}157 \\
94\end{array}$ & $\begin{array}{l}62.5 \\
37.5\end{array}$ \\
\hline ITN availability & $\begin{array}{l}\text { Yes } \\
\text { No }\end{array}$ & $\begin{array}{l}247 \\
4\end{array}$ & $\begin{array}{l}98.4 \\
1.6\end{array}$ \\
\hline
\end{tabular}

cases were $83.3 \%$ (25/30) $P$. vivax and $16.7 \%(5 / 30)$ $P$. falciparum. The highest prevalence of asymptomatic Plasmodium infection was observed in the age group 15-29 years $(4.4 \%)$. There were no significant differences in the prevalence of asymptomatic Plasmodium infection among sex and age groups (Table 2).

\section{Level of Parasitemia by Sex and Age Group}

The majority ( $70 \%$ ) of study participants had $<500$ parasites $/ \mu \mathrm{L}$ of blood ( $40 \%$ in males and $30 \%$ in females); $23.3 \%$ and $6.7 \%$ of individuals had $500-1000$ and $\geq 1000$ parasites $/ \mu \mathrm{L}$ of blood, respectively. The highest parasitemia level ( $\geq 1000$ parasites $/ \mu \mathrm{L}$ of blood) was observed in the age group 15-29 years and the lowest parasitemia level
$(<500 / \mu \mathrm{L}$ of blood) was observed in individuals $<5$ years old. The mean parasitemia level of P. falciparum was 640 parasites $/ \mu \mathrm{L}$ of blood (range 320-880) and the mean parasitemia of $P$. vivax was 555.5 parasites $/ \mu \mathrm{L}$ of blood (range 120-3200). There were no significant differences in the level of parasitemia among sex $\left(\chi^{2}=3.88 ; P=0.143\right)$ and age groups $\left(\chi^{2}=6.64 ; P=0.576\right)$.

\section{Risk Factors of Asymptomatic Plasmodium Infection}

Risk factor assessment generally showed that age group, bed net usage and previous history of malaria were significantly associated with asymptomatic Plasmodium infection $(P<0.05)$, while sex, IRS coverage and family size were not significantly associated with asymptomatic Plasmodium infection $(P>0.05)$ (Table 3).

Individuals in the age group 15-29 years were 6.36 times [AOR $=6.36,95 \%$, CI: $1.30-30.97]$ more likely to have asymptomatic Plasmodium infection. Individuals who did not use bed nets were 24.8 times [AOR=24.8, 95\% CI: 8.2674.56] more likely to have asymptomatic Plasmodium infection. In addition, study participants who used bed nets sometimes were 5.12 times [AOR $=5.12,95 \%$, CI: 1.25-2.82] more likely to be infected by Plasmodium parasites. Individuals who had previous history of malaria were 3.69 times [AOR=3.69, 95\%, CI: 1.06-12.78] more likely to have asymptomatic Plasmodium infection than those who had no previous history of malaria (Table 3).

\section{Discussion}

Asymptomatic Plasmodium infections are common in areas of unstable and seasonal patterns of transmission. The detection and quantification of Plasmodium parasite in asymptomatic individuals are important for the reduction of transmission, control and elimination of malaria. However, diagnosis of asymptomatic malaria is becoming a challenge owing to low levels of parasitemia and the absence of more sensitive diagnostic tools. At this time, asymptomatic individuals serve as potential gametocyte carriers and transmitters, which results in sustained malaria transmission within a population regardless of effective treatment of active cases. ${ }^{6,17}$ The current study aimed to assess the magnitude of asymptomatic Plasmodium infection and associated factors in Gondar Zuria district, Northwest Ethiopia.

In the present study, a high prevalence of asymptomatic Plasmodium infection was observed (12\%) despite high coverage of mosquito bed nets in this geographical setting. This 
Table 2 Prevalence of Asymptomatic Plasmodium Infection by Sex and Age Group in Gondar Zuria District, Northwest Ethiopia, 2019

\begin{tabular}{|c|c|c|c|c|c|c|c|}
\hline & \multicolumn{4}{|c|}{ Asymptomatic Plasmodium Infection Status } & \multirow[t]{2}{*}{ Total } & \multirow[t]{2}{*}{$\chi^{2}$} & \multirow[t]{2}{*}{$P$-value } \\
\hline & Positive (n) & Percentage (\%) & Negative (n) & Percentage (\%) & & & \\
\hline \multicolumn{8}{|l|}{ Sex } \\
\hline Male & 14 & 5.6 & 103 & 41.0 & 117 & 0.67 & 0.41 \\
\hline Female & 16 & 6.4 & 118 & 47.0 & 134 & & \\
\hline Total & 30 & 12 & 221 & 88.0 & 251 & & \\
\hline \multicolumn{8}{|c|}{ Age group (years) } \\
\hline$<5$ & 5 & 2 & 28 & 11.2 & 33 & 2.26 & 0.68 \\
\hline $5-14$ & 7 & 2.8 & 74 & 29.5 & 81 & & \\
\hline $15-29$ & II & 4.4 & 42 & 16.7 & 53 & & \\
\hline 30 and above & 7 & 2.8 & 77 & 30.6 & 84 & & \\
\hline Total & 30 & 12 & 221 & 88 & 251 & & \\
\hline
\end{tabular}

Table 3 Bivariate and Multivariate Analysis of Factors Associated with Asymptomatic Plasmodium Infection in Gondar Zuria District, Northwest Ethiopia, May to June 2019

\begin{tabular}{|c|c|c|c|c|c|c|c|}
\hline \multicolumn{2}{|l|}{ Variables } & \multicolumn{3}{|c|}{ Malaria } & \multicolumn{2}{|l|}{ OR $(95 \% \mathrm{CI})$} & \multirow{3}{*}{$\begin{array}{l}\text {-value } \\
0.312\end{array}$} \\
\hline & & Pos & Neg & Total & COR & AOR & \\
\hline Sex & $\begin{array}{l}\text { Male } \\
\text { Female }\end{array}$ & $\begin{array}{l}14 \\
16\end{array}$ & $\begin{array}{l}103 \\
118\end{array}$ & $\begin{array}{l}117 \\
134\end{array}$ & $\begin{array}{l}1.002(0.46-2.15) \\
1\end{array}$ & $\begin{array}{l}0.59(0.2 \mathrm{I}-\mathrm{I} .64) \\
\mathrm{I}\end{array}$ & \\
\hline Age group (years) & $\begin{array}{l}<5 \\
5-14 \\
15-29 \\
30 \text { and above }\end{array}$ & $\begin{array}{l}5 \\
7 \\
11 \\
7\end{array}$ & $\begin{array}{l}28 \\
74 \\
42 \\
77\end{array}$ & $\begin{array}{l}33 \\
81 \\
53 \\
84\end{array}$ & $\begin{array}{l}2.73(0.60-12.35) \\
1.45(0.37-5.89) \\
4.01(1.04-15.38) \\
I\end{array}$ & $\begin{array}{l}2.30(0.38-13.69) \\
2.58(0.50-13.13) \\
6.36(1.30-30.97) \\
1\end{array}$ & $\begin{array}{l}0.357 \\
0.252 \\
0.022\end{array}$ \\
\hline Family size & $\begin{array}{l}\leq 5 \\
>5\end{array}$ & $\begin{array}{l}8 \\
22\end{array}$ & $\begin{array}{l}73 \\
148\end{array}$ & $\begin{array}{l}81 \\
170\end{array}$ & $\begin{array}{l}\text { I } \\
1.35(0.57-3.19)\end{array}$ & $\begin{array}{l}\text { I } \\
\text { I.39 (0.44-4.34) }\end{array}$ & 0.56 \\
\hline Previous history of malaria & $\begin{array}{l}\text { Yes } \\
\text { No }\end{array}$ & $\begin{array}{l}26 \\
4\end{array}$ & $\begin{array}{l}131 \\
90\end{array}$ & $\begin{array}{l}157 \\
94\end{array}$ & $\begin{array}{l}5.08(1.71-15.05) \\
1\end{array}$ & $\begin{array}{l}3.69(1.06-12.78) \\
1\end{array}$ & 0.039 \\
\hline ITN usage & $\begin{array}{l}\text { Daily } \\
\text { Sometimes } \\
\text { Never }\end{array}$ & $\begin{array}{l}5 \\
4 \\
21\end{array}$ & $\begin{array}{l}166 \\
27 \\
28\end{array}$ & $\begin{array}{l}171 \\
31 \\
49\end{array}$ & $\begin{array}{l}\text { I } \\
4.91(1.24-19.47) \\
24.9(8.67-71.46)\end{array}$ & $\begin{array}{l}\text { I } \\
5.12(1.25-20.82) \\
24.8(8.26-74.56)\end{array}$ & $\begin{array}{l}0.023 \\
0.001\end{array}$ \\
\hline IRS coverage & $\begin{array}{l}\text { Within a year } \\
\text { More than a year }\end{array}$ & $\begin{array}{l}9 \\
21\end{array}$ & $\begin{array}{l}105 \\
116\end{array}$ & $\begin{array}{l}114 \\
137\end{array}$ & $\begin{array}{l}\text { I } \\
0.47(0.20-1.08)\end{array}$ & $\begin{array}{l}\text { I } \\
0.38(0.14-1.02)\end{array}$ & 0.056 \\
\hline
\end{tabular}

Abbreviations: Pos, positive; Neg, negative; OR, odds ratio; COR, crude odds ratio; AOR, adjusted odds ratio.

may be the effect of climate change on highland malaria transmission, which is strongly dependent on the temperature as it influences population growth of the mosquito vector and pathogen development within the vector. ${ }^{8}$ This is comparable with the study conducted in Dilla town, Ethiopia and the surrounding rural areas $(16 \%) .{ }^{18}$ However, it is lower than in the studies conducted in East Shewa zone, Oromia, Ethiopia $(25 \%),{ }^{19}$ Nigeria $(41.6 \%),{ }^{20}$ Tanzania $(36.3 \%)^{21}$ and India $(27.6 \%){ }^{22}$ Moreover, it is higher than in the study conducted in different regions (Oromia, Amhara and SNNP) of Ethiopia $(4.1 \%),{ }^{23}$ in Benna Tsemay district, Southern Ethiopia
(6.1\%), ${ }^{24}$ and West Arsi Zone, Ethiopia (5\%). ${ }^{14}$ The possible reasons for the difference could be differences in study design, geographical location (rainfall, temperature and altitude), quality of houses, nature of population, sample size, study period and the implemented malaria control program in the study area.

In this study, the proportion of Plasmodium species showed the dominance of $P$. vivax $(83.3 \%)$ over P. falciparum (16.7\%) infections. This finding is in line with the studies conducted in Hadiya zone, Southern Ethiopia, ${ }^{25}$ and East Shewa zone, Ethiopia ${ }^{19,26}$ which 
also showed the dominance $P$. vivax over $P$. falciparum. In contrast, a nationwide report in Ethiopia, ${ }^{27,28}$ and studies conducted in Sanja, ${ }^{15}$ Pawe $^{29}$ and Mirab Abaya, ${ }^{30}$ showed the predominance of $P$. falciparum. This difference may be due to variation in the epidemiological distribution of Plasmodium species in different part of Ethiopia and to the presence of relapse for $P$. vivax.

A high prevalence of asymptomatic Plasmodium infection was seen in the age group 15-29 years and the highest parasitemia level was also observed in this age group. This may be due to the fact that such individuals are mobile or have traveled to malaria-endemic lowland areas seeking temporary employment and returned to their home area, which increases the risk of acquiring Plasmodium infection. This finding is supported by a study conducted in Dabat district, Northwest Ethiopia. ${ }^{31}$

Malaria infection was significantly associated with previous history of malaria. This is comparable with a study conducted in Sanja, Northwest Ethiopia. ${ }^{15}$ One possible explanation for this could be due to the recurrence of malaria infection after clinical cure. The risk of malaria infection was higher in those individuals who had a previous history of malaria. This may be due to family members with a history of malaria infection becoming a reservoir for the Plasmodium parasite and a source of infection for the rest of the family.

There was a statistically significant association between asymptomatic Plasmodium infection and bed net utilization. The odds of being infected with malaria were higher in those individuals who did not used bed nets and in those using them occasionally than in those who used bed nets daily $(P<0.05)$. This finding is supported by studies conducted in Ethiopia $^{25,29}$ and Nigeria. ${ }^{20}$ It is noticeable that using a bed net daily reduces the risk of malaria infection by preventing human-mosquito contact. ITNs provide protection both to the individuals sleeping under them by deterring mosquito bites and to family members by killing mosquitoes, thereby reducing the transmission of malaria parasites.

\section{Limitations}

Lack of molecular evidence, recall bias on the history of malaria and the study period could affect the results.

\section{Conclusion}

Asymptomatic Plasmodium infection is an important public health concern in Gondar Zuria district. Screening and treatment of asymptomatic cases using more sensitive diagnostic methods is vital to evaluate the burden of asymptomatic
Plasmodium infection and to scale up the malaria elimination and eradication program in the country.

\section{Abbreviations}

$\mathrm{ACT}$, artemisinin combination therapy; $\mathrm{CQ}$, chloroquine; IRS, indoor residual spraying; LLITN, long-lasting insecticide-treated net; RDT, rapid diagnostic test; WHO, World Health Organization.

\section{Data Sharing Statement}

The datasets used and/or analyzed during the current study are available from the corresponding author upon reasonable request.

\section{Ethical Approval and Consent to Participate}

This study was conducted in accordance with the Declaration of Helsinki. Ethical clearance was obtained from the ethical committee of School of Biomedical and Laboratory Sciences, University of Gondar (Ref. No. SBLS/2118/11). Permission from Gondar Zuria district Health Office and kebele administrations was also obtained and information about the objective of the study was given to the head of each household. Written informed consent was obtained from adult participants and from parents/guardians for children. Blood tests were performed free of charge and malaria cases were treated as per the national malaria treatment guideline.

\section{Acknowledgments}

We would like to thank University of Gondar for funding this research. We are grateful to data collectors and study participants.

\section{Funding}

The research was funded by University of Gondar for collection of data.

\section{Disclosure}

The authors report no conflict of interests in this work.

\section{References}

1. World Health Organization. World Malaria Report 2017. Geneva: WHO; 2017.

2. Deribew A, Dejene T, Kebede B, et al. Incidence, prevalence and mortality rates of malaria in Ethiopia from 1990 to 2015: analysis of the global burden of diseases 2015. Malar J. 2017;16(1):271. doi:10.1186/s12936-017-1919-4 
3. Federal Ministry Of Health. National Malaria Program Monitoring and Evaluation Plan 2014-2020. Addis Ababa; 2014.

4. Williams J, Pinto J. Training Manual on Malaria Entomology for Entomology and Vector Control Technicians (Basic Level). Washington, DC: USAID; 2012:78.

5. World Health Organization. World Malaria Report 2018. Geneva: World Health Organization; 2018.

6. Ouédraogo AL, Bousema T, Schneider P, et al. Substantial contribution of submicroscopical Plasmodium falciparum gametocyte carriage to the infectious reservoir in an area of seasonal transmission. PLoS One. 2009;4(12):e8410. doi:10.1371/journal.pone.0008410

7. World Health Organization. World Malaria Report 2014. World Health Organization; 2015.

8. President's Malaria initiative Ethiopia. Malaria operational plan. FY2018.

9. President's Malaria Initiative: Ethiopia. Malaria Operational Plan FY2017.

10. Federal Ministry of Health. National Malaria Guidelines (3rd Edn). Addis Ababa: Federal Ministry of Health; 2012:3-59.

11. Rowe AK, Rowe SY, Snow RW, et al. The burden of malaria mortality among African children in the year 2000. Int J Epidemiol. 2006;35(3):691-704. doi:10.1093/ije/dyl027

12. Ethiopian Public Health Institute. Ethiopian National Malaria Indicator Survey 2015. Addis Ababa: Ethiopian Public Health Institute; 2016.

13. Central Statistical Agency. National Population and Housing Census of Ethiopia: Population Projection of Ethiopia for All Regions, at Wereda Level from 2014-2017. Ethiopian Central Statistics Agency; November, 2018.

14. Golassa L, Baliraine FN, Enweji N, Erko B, Swedberg G, Aseffa A. Microscopic and molecular evidence of the presence of asymptomatic Plasmodium falciparum and Plasmodium vivax infections in an area with low, seasonal and unstable malaria transmission in Ethiopia. BMC Infect Dis. 2015;15(1):310. doi:10.1186/s12879-015-1070-1

15. Worku L, Damtie D, Endris M, Getie S, Aemero M. Asymptomatic malaria and associated risk factors among school children in Sanja Town, Northwest Ethiopia. Int Sch Res Notices. 2014;303269:1-6. doi: $10.1155 / 2014 / 303269$

16. FE PW M, Magill AJ, Forney JR, et al. White blood cell counts and malaria. J Infect Dis. 2005;2(192):323-330.

17. Kamanga A, Moono P, Stresman G, Mharakurwa S, Shiff C. Rural health centres, communities and malaria case detection in Zambia using mobile telephones: a means to detect potential reservoirs of infection in unstable transmission conditions. Malar J. 2010;9(1):96. doi:10.1186/1475-2875-9-96

18. Molla E, Ayele B. Prevalence of malaria and associated factors in Dilla Town and the surrounding rural Areas, Gedeo Zone, Southern Ethiopia. J Bacteriol Parasitol. 2015;6(5):1-7.
19. Tadesse F, Fogarty A, Deressa W. Prevalence and associated risk factors ofmalaria among adults in East Shewa Zoneof Oromia Regional State, Ethiopia: across-sectional study. BMC Public Health. 2018;18:25. doi:10.1186/s12889-017-4577-0

20. Fana SA, Bunza MD, Anka SA, Imam AU, Nataala SU. Prevalence and risk factors associated with malaria infection among pregnant women in a semi-urban community of north-western Nigeria. Infect Dis Poverty. 2015;4(24):1-5.

21. Sumari D, Mwingira F, Selemani M, Mugasa J, Mugittu K, Gwakisa P. Malaria prevalence in asymptomatic and symptomatic children in Kiwangwa, Bagamoyo district, Tanzania. Malar J. 2017;16(1):222. doi:10.1186/s12936-017-1870-4

22. Chourasia M, Raghavendra K, Bhatt R, Swain D, Valecha N, Kleinschmidt I. Burden of asymptomatic malaria among a tribal population in a forested village of central India: a hidden challenge for malaria control in India. Public Health. 2017;147:9 2-9 7. doi:10.1016/j.puhe.2017.02.010

23. Graves PM, Richards FO, Ngondi J, et al. Individual, household and environmental risk factors for malaria infection in Amhara, Oromia and SNNP regions of Ethiopia. Trans $R$ Soc Trop Med Hyg. 2009;016:1-10.

24. Debo GW, Kassa DH. Prevalence of malaria and associated factors in Benna Tsemay district of pastoralist community, Southern Ethiopia. Trop Dis Travel Med Vaccines. 2016;2(16):1-9.

25. Delil RK, Dileba TK, Habtu YA, Gone TF, Leta TJ. Magnitude of malaria and factors among febrile cases in low transmission areas of Hadiya Zone, Ethiopia: a Facility Based cross-sectional Study. PLoS One. 2016;11(5):1-17.

26. Haji Y, Fogarty AW, Deressa W. Prevalence and associated factors of malaria among febrile children in Ethiopia: a cross-sectional health facility-based study. Acta Trop. 2016;155:63-70. doi:10.1016/j. actatropica.2015.12.009

27. Federal Ministry of Health (FMoH). Ethiopian National Malaria Indicator Survey 2011. Addis Ababa, Ethiopia: FMoH; 2012c.

28. Federal Ministry of Health (FMoH). Ethiopian National Malaria Indicator Survey 2015. Addis Ababa, Ethiopia: FMoH; 2016.

29. Beyene HB, Telele NF, Mekuria AH. Asymptomatic malaria and associated factors in Pawe, Northern Ethiopia. Int $J$ Infect Dis Tropical Medicine. 2015;2(2):60-69. doi:10.14194/ijitd.2.2.5

30. Abossie A, Bekele A, Yohanes T, Abera A. Prevalence of asymptomatic P. falciparum and Plasmodium vivax malaria carriage among school children of malaria endemic areas of Mirab Abaya district, Southern Ethiopia. J Parasit Vectors Biol. 2017;9(1):1-7.

31. Alemu K, Worku A, Berhane Y, Kumie A, Snounou G. Men traveling away from home are more likely to bring malaria into high altitude villages, northwest Ethiopia. PLoS One. 2014;9(4):e95341. doi:10.1371/journal.pone.0095341
Infection and Drug Resistance

\section{Publish your work in this journal}

Infection and Drug Resistance is an international, peer-reviewed openaccess journal that focuses on the optimal treatment of infection (bacterial, fungal and viral) and the development and institution of preventive strategies to minimize the development and spread of resistance. The journal is specifically concerned with the epidemiology of antibiotic resistance and the mechanisms of resistance development and diffusion in both hospitals and the community. The manuscript management system is completely online and includes a very quick and fair peerreview system, which is all easy to use. Visit http://www.dovepress.com/ testimonials.php to read real quotes from published authors. 